DOI: https://doi.org/10.24127/ajpm.v10i2.3510

\title{
ANALISIS KESULITAN DALAM PEMECAHAN MASALAH MATEMATIKA DITINJAU DARI MINAT BELAJAR PESERTA DIDIK BERDASARKAN LANGKAH POLYA
}

\author{
Yulia Haryono $^{1 *}$, Ratulani Juwita ${ }^{2}$, Shinta Vioni ${ }^{3}$ \\ ${ }^{1 *, 2,3}$ Pendidikan Matematika STKIP PGRI Sumatera Barat, Padang, Indonesia \\ *Corresponding author. Padang, Sumatera Barat, Indonesia \\ E-mail: $\quad y$ uliaharyono85@gmail.com ${ }^{1 *}$ \\ ratulanijuwita@gmail.com $\left.{ }^{2}\right)$ \\ shintavioni01@gmail.com $^{3)}$
}

Received 26 January 2021; Received in revised form 28 June 2021; Accepted 29 June 2021

\begin{abstract}
Abstrak
Tujuan penelitian ini adalah untuk mengetahui bagaimana kesulitan dalam pemecahan masalah matematika ditinjau dari minat belajar dan apa saja faktor penyebab peserta didik mengalami kesulitan dalam pemecahan masalah matematika ditinjau dari minat belajar. Penelitian menggunakan metode deskriptif dengan pendekatan kualitatif. Subjek penelitian dipilih secara purposive sampling yaitu berjumlah 6 orang, 2 orang minat belajar tinggi, 2 orang minat belajar sedang dan 2 orang minat belajar rendah. Instrumen yang digunakan adalah angket minat belajar, soal tes pemecahan masalah dan wawancara. Angket minat belajar dianalisis berdasarkan pengelompokan minat belajar, tes pemecahan masalah dianalisis berdasarkan indikator kesulitan dalam pemecahan masalah dan wawancara dianalisis secara kualitatif menurut Milles dan Huberman. Hasil penelitian menunjukkan bahwa peserta didik dengan minat belajar tinggi mengalami kesulitan dalam memeriksa kembali, peserta didik dengan minat belajar sedang mengalami kesulitan dalam menyelesaikan rencana penyelesaian dan memeriksa kembali, serta peserta didik dengan minat belajar rendah mengalami kesulitan dalam menyusun rencana penyelesaian, menyelesaikan rencana penyelesaian dan memeriksa kembali. Kesulitan dalam pemecahan masalah matematika disebabkan oleh peserta didik bosan belajar matematika, tidak menyukai pelajaran matematika, belum terfokus dengan materi yang dijelaskan guru, tidak memiliki semangat untuk menyimak materi yang diberikan guru, tidak berani mengemukakan pendapat dan tidak bersemangat menyelesaikan soal matematika tidak rutin.
\end{abstract}

Kata kunci: Analisis kesulitan; minat belajar; pemecahan masalah matematika.

\begin{abstract}
This research was to find out how difficult it was in solving students' mathematical problems in terms of learning interest and what are the factors students to experience difficulties in solving mathematical problems in terms of learning interest. This type of research is a descriptive method with a qualitative approach. The research subjects were selected by purposive sampling, namely 6 students, 2 high learning interest, 2 moderate learning interest, and 2 low learning interest. The instruments used were the interest in learning questionnaire, problem solving test, and interviews. Interest in learning questionnaires were analyzed based on grouping interest in learning, problem solving tests were analyzed based on indicators of difficulty in problem solving and interviews were analyzed qualitatively according to Milles and Huberman. The results of the study were students who had a high interest in learning experienced difficulty in checking back, students who had an interest in learning were had difficulty to complete the plan and checking again, and students who had a low interest in learning had difficulty in arranging plan and check back. Difficulties in solving math problems were caused by students who were bored with learning mathematics, did not like lessons, have not focused on the material described by the teacher, did not have enthusiasm about listening to the mathematics material provided by the teacher, did not dare to put forward and are not enthusiastic about working on irregular math problems.
\end{abstract}

Keywords: Difficulty analysis; interest to learn; math problem solving. 
DOI: https://doi.org/10.24127/ajpm.v10i2.3510

\section{PENDAHULUAN}

Matematika merupakan salah satu mata pelajaran yang dibutuhkan oleh peserta didik untuk memecahkan masalah dalam kehidupannya. Berdasarkan asal katanya, kata matematika berarti ilmu pengetahuan yang didapat dengan berpikir (bernalar) (Muhammad Daud Siagian, 2016). Artinya, matematika memudahkan dalam berpikir menggunakan logika dan nalar. Hal tersebut sangat dibutuhkan dalam kemampuan pemecahan masalah. Kemampuan pemecahan masalah merupakan salah satu kemampuan yang harus dikuasai peserta didik. Hal ini sesuai dengan pendapat NCTM (2000) bahwa terdapat lima kemampuan dasar dalam matematika, yaitu pemecahan masalah (problem solving), penalaran dan pembuktian (reasoning and proof), komunikasi (communication), koneksi (connections), dan representasi (representasion).

Pemecahan masalah telah menjadi komponen penting dalam matematika pendidikan. Pemecahan masalah adalah upaya yang dilakukan guna menyelesaikan permasalahan yang ditemukan dengan menggunakan pengetahuan serta keterampilan yang sudah ada untuk mencapai tujuan pengajaran. (Albay, 2019) menyebutkan bahwa mengembangkan kemampuan siswa dalam memecahkan masalah merupakan bagian integral dari pembelajaran matematika di semua tingkatan. Siswa dapat belajar dan memahami matematika melalui pemecahan masalah secara matematis.

Ketika peserta didik diberikan masalah dan peserta didik tidak bisa menyelesaikan masalah tersebut dengan benar, maka bisa dikatakan peserta didik mengalami kesulitan dalam pemecahan masalah matematika (Mahdayani, 2016). Alasan inilah yang menjadi penyebab Peserta didik cenderung sulit dalam memecahkan permasalahan baik berkaitan dengan soal maupun masalah kehidupan seharihari.

Charles dan Laster dalam Kaur Berinderject menyebutkan bahwa minat merupakan faktor yang mempengaruhi kemampuan pemecahan masalah dari seseorang (Hermaini, 2020). Peserta didik dengan minat belajar tinggi akan merasa tertantang untuk memecahkan masalah dalam suatu permasalahan yang diberikan serta cenderung berkemauan besar untuk belajar dalam kondisi apapun. Jika minat belajar peserta didik rendah, maka kemampuannya untuk memecahkan suatu permasalahan akan terhambat.

Terdapat penelitian sebelumnya yang meneliti tentang kesulitan pemecahan masalah yaitu (Sapitri et al., 2019) meneliti tentang minat belajar siswa dalam soal pemecahan masalah dalam kategori minat belajar yang sedang, (Khasanah et al., 2021) menyatakan masalah yang dialami siswa adalah kesulitan dalam pemecahan masalah abstraksi matematis, (Rasiman, 2016) meneliti tentang kesulitan siswa dalam menyelesaikan masalah matematika ditinjau dari gaya kognitif, dan (Ruhyana, 2016) meneliti tentang kesulitan siswa dalam pemecahan masalah matematika, faktor penyebab serta penanganan kesulitan siswa dalam pemecahan masalah matematika.

Kesulitan dalam pemecahan masalah matematika dialami oleh peserta didik kelas VIII.7 SMP Negeri 31 Padang. Berdasarkan observasi yang dilakukan, ditemukan banyak peserta didik mengalami kesulitan saat menyelesaikan masalah matematika. Peserta didik mengalami kesulitan saat mengaplikasikan rumus ke dalam soal 
yang diberikan oleh guru, terlebih ketika soal tersebut berbentuk essay atau soal cerita. Peserta didik kurang antusias saat mengikuti pembelajaran. Peserta didik juga harus selalu diingatkan dan dimotivasi untuk selalu belajar. Terlihat sudah adanya gambaran bahwa peserta didik mengalami kesulitan saat menyelesaikan soal pemecahan masalah matematika. Penyebabnya adalah karena kurangnya minat belajar peserta didik terhadap pelajaran matematika. Hal ini sesuai dengan pendapat Charles dan Laster dalam Kaur Berinderject yang menyebutkan bahwa minat merupakan faktor yang mempengaruhi kemampuan pemecahan masalah dari seseorang (Hermaini, 2020). Maka dilakukan analisis secara mendalam untuk mengetahui bagaimana kesulitan yang dialami peserta didik dalam menyelesaikan soal pemecahan masalah matematika yang ditinjau dari minat belajar dan apa saja faktor penyebab peserta didik mengalami kesulitan dalam pemecahan masalah matematika ditinjau dari minat belajar.

\section{METODE PENELITIAN}

Penelitian ini menggunakan metode analisis deskriptif dengan pendekatan kualitatif. Prosedur yang ditempuh dalam pengambilan data pada penelitian ini dilakukan melalui tiga tahap, yaitu tahap persiapan, tahap pelaksanaan dan tahap akhir. Pada tahap persiapan, dipersiapkan segala sesuatu yang berhubungan dengan pelaksanaan mulai dari mempersiapkan surat izin observasi dan penelitian, melakukan observasi, menyusun proposal, merancang instrumen penelitian, menentukan subjek, dll. Pada tahap pelaksanaan, memberikan angket minat belajar kepada peserta didik, memberikan tes pemecahan masalah matematika, dan melakukan wawancara. Pada tahap akhir adalah mengolah dan menganalisis data yang telah diperoleh. Penelitian ini dilaksanakan pada semester ganjil Tahun Ajaran 2020/2021 di kelas VIII.7 SMP Negeri 31 Padang. Subjek penelitian dipilih secara purposive sampling yaitu 2 orang minat belajar tinggi, 2 orang minat belajar sedang dan 2 orang minat belajar rendah. Instrumen yang digunakan adalah angket minat belajar, soal tes pemecahan masalah, dan pedoman wawancara. Teknik pengumpulan data berupa metode angket, metode tes dan wawancara. Angket minat belajar disusun berdasarkan indikator minat belajar yaitu terdiri dari : perasaan senang, ketertarikan siswa,keterlibatan siswa, rajin dalam belajar dan rajin mengerjakan tugas matematika serta tekun dan displin dalam belajar dan memiliki jadwal belajar (Hendriana et al., 2017). Angket tersebut telah dimodifikasi sesuai dengan kebutuhan pembelajaran. Setelah angket tersebut dimodifikasi maka dilakukan validasi kembali oleh dosen pembimbing. Sedangkan tes yang digunakan adalah soal tes berbentuk uraian mengenai soal pemecahan masalah matematika. Sebelum diujikan, soal terlebih dahulu divalidasi oleh dosen pembimbing dan guru matematika SMP Negeri 31 Padang. Serta wawancara tidak terstruktur adalah pedoman wawancara yang digunakan pada penelitian ini.

Angket minat belajar dianalisis berdasarkan pengelompokan minat belajar siswa dengan kategori pengelompokan yang dikemukakan oleh Sudijono dalam (Komariyah et al., 2018). Sedangkan hasil jawaban peserta didik dihitung menggunakan rubrik menurut (Ariani et al., 2017) yang dimodifikasi. Menurut (Herlambang, 
2013) langkah-langkah pemecahan masalah matematika Polya sangat mudah dimengerti dan sangat sederhana, kegiatan yang dilakukan setiap langkah jelas serta secara eksplisit mencakup semua langkah pemecahan masalah dari pendapat ahli lain. Indikator pemecahan masalah berdasarkan tahapan Polya terdiri dari memahami masalah, menyusun rencana penyelesaian, menyelesaikan rencana penyelesaian dan memeriksa kembali. Kemudian dianalisis kesulitan dalam pemecahan masalah berdasarkan indikator kesulitan dalam pemecahan masalah oleh (Sulistiyorini \& Setyaningsih, 2016) yang dimodifikasi yaitu kesulitan dalam memahami masalah, kesulitan dalam menyusun rencana, kesulitan dalam melaksanakan rencana, dan kesulitan dalam memeriksa kembali. Kesulitan pemecahan masalah ditinjau dari kelompok minat belajar yaitu minat tinggi, minat sedang dan minat rendah. Untuk mengklarifikasi hasil tes tertulis, mengungkap kesulitan peserta didik dalam pemecahan masalah matematika ditinjau dari minat, serta faktor penyebab kesulitan pada hasil tes dilakukan wawancara. Data hasil wawancara dianalisis berdasarkan teknis analisis data menurut Milles dan Huberman (1992) yaitu reduksi data, penyajian data dan penarikan kesimpulan atau verifikasi.

\section{HASIL DAN PEMBAHASAN}

Penelitian telah dilakukan kepada peserta didik yang telah mempelajari materi bidang kartesius di kelas VIII.7 SMP Negeri 31 Padang sebanyak 32 orang. Mengenai banyaknya subjek yang dipilih berdasarkan tingkatan minat dan disesuaikan dengan data hasil tes pemecahan masalah diperoleh peserta didik dengan minat belajar tinggi sebanyak 2 orang yaitu peserta didik MA dan PAS, peserta didik dengan minat belajar sedang sebanyak 2 orang yaitu peserta didik $\mathrm{KN}$ dan $\mathrm{SA}$ dan peserta didik dengan minat belajar rendah sebanyak 2 orang yaitu peserta didik HAF dan LAH.

Penelitian bertujuan untuk mengetahui bagaimana kesulitan dalam pemecahan masalah matematika ditinjau dari minat belajar peserta didik dan faktor yang menyebabkan peserta didik mengalami kesulitan dalam pemecahan masalah matematika ditinjau dari minat belajar. Tingkatan minat belajar peserta didik sebagai berikut: minat belajar tinggi, minat belajar sedang, dan minat belajar rendah. Berdasarkan ketiga tingkatan minat belajar tersebut, dianalisis kesulitan dalam pemecahan masalah matematika dengan indikator kesulitan dalam pemecahan masalah.

\section{Kesulitan dalam Pemecahan Masalah Matematika}

Minat Belajar Tinggi

Berdasarkan hasil angket minat belajar, peserta didik dengan minat belajar tinggi memiliki perasaan senang terhadap pembelajaran matematika, ketertarikan ketika belajar matematika namun belum terfokus pada materi yang diberikan guru, peserta didik terlibat selama pembelajaran matematika, rajin mengerjakan tugas tambahan serta tekun dalam belajar. Untuk mengetahui kesulitan yang dialami peserta didik dengan minat tinggi dalam menyelesaikan soal pemecahan masalah matematika, berikut disajikan lembar jawaban dan wawancara dengan peserta didik MA pada Gambar 1. Sebelumnya, untuk soal nomor 3, yaitu:

"Setiap hari Andi pergi ke sekolah, untuk pergi ke sekolah Andi harus bersepeda sejauh $100 \mathrm{~m}$ ke arah Barat 
DOI: https://doi.org/10.24127/ajpm.v10i2.3510

lalu belok 500 meter ke arah Utara kemudian Andi harus belok 100 meter ke arah Timur untuk sampai ke sekolahnya. Tentukan posisi garis rute Andi yang sejajar dan tegak lurus terhadap sumbu $x$ dan sumbu $y$ !"

Sedangkan, untuk hasil wawancara adalah sebagai berikut (P: Penanya dan MA: Subjek Penelitian). $P$ : Nah, setelah Adek menyelesaikan soal nomor 3 ini apakah Adek memeriksa kembali jawaban yang Adek buat?

MA: Tidak kak

$P$ : Kenapa gitu?

MA: Udah malas aja lagi kak

$\mathrm{P}$ : Kira-kira menurut Adek, jawaban Adek ini sudah benar atau bagaimana?

MA: Sudah kak hehe...

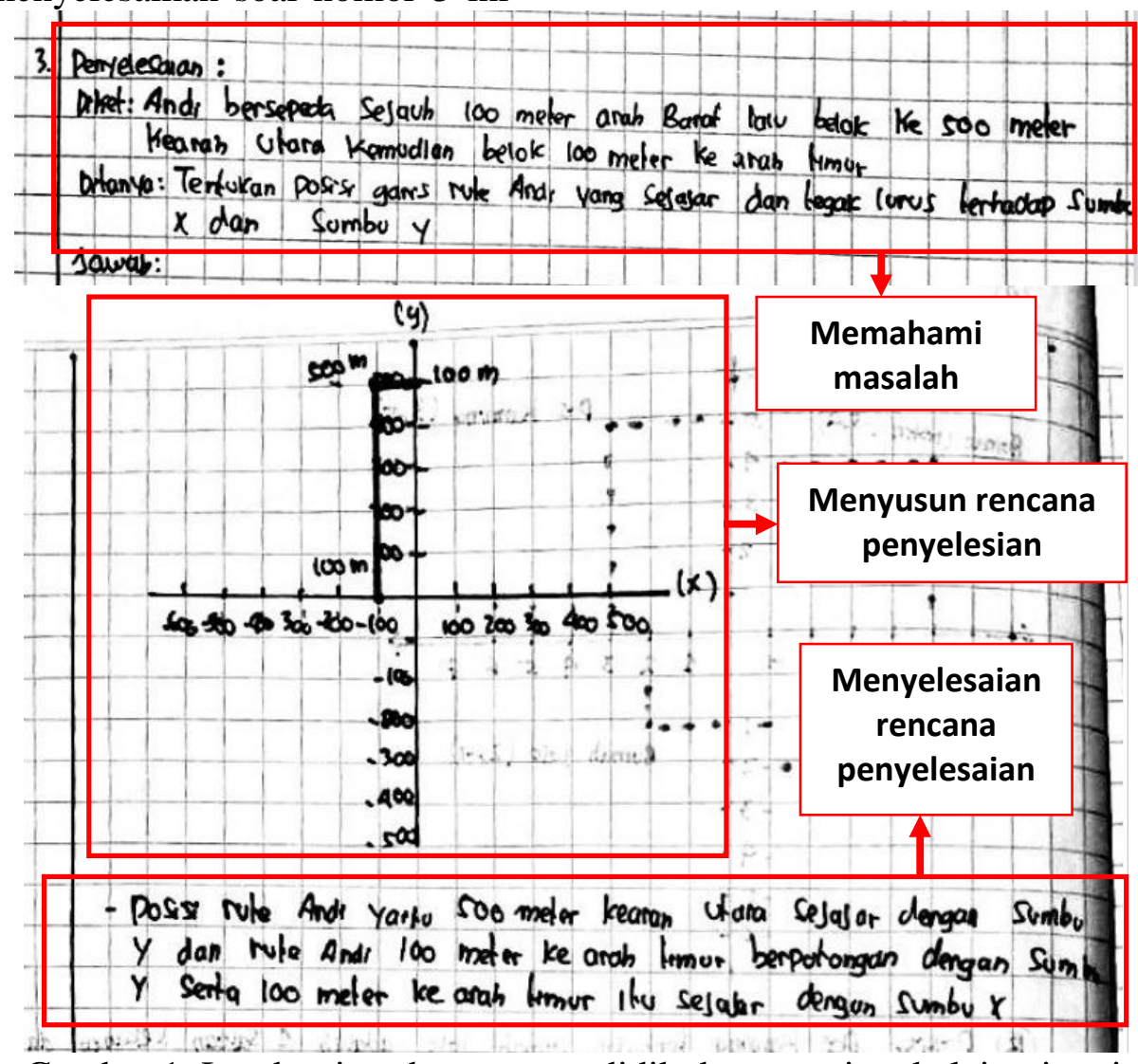

Gambar 1. Lembar jawaban peserta didik dengan minat belajar tinggi

Berdasarkan lembar jawaban pada Gambar 1 dan hasil wawancara dengan peserta didik, terlihat bahwa kesulitan peserta didik dalam memeriksa kembali adalah peserta didik tidak menuliskan kesimpulan serta tidak melakukan pengecekan kembali penyelesaiannya. Peserta didik hanya membuat bidang koordinat dan langkah penyelesaian untuk menentukan garis yang sejajar dan tegak lurus terhadap sumbu $\mathrm{x}$ dan sumbu y tanpa menuliskan kesimpulan.
Peserta didik tidak memeriksa kembalu jawabannya karena malas untuk memeriksa jawaban yang dibuatnya dan merasa jawabannya sudah benar.

Minat Belajar Sedang

Berdasarkan hasil angket minat belajar, peserta didik dengan minat belajar senang memiliki perasaan senang saat belajar matematika, bersemangat ketika pembelajaran matematika meskipun kadang merasa 
bosan dan belum terfokus pada materi yang dijelaskan guru, peserta didik terlibat selama pembelajaran matematika namun kurang bersemangat mengerjakan soal-soal matematika yang tidak rutin dan rajin dalam mengerjakan tugas matematika akan serta tekun dan disiplin dalam belajar. Untuk mengetahui kesulitan yang dialami peserta didik dengan minat sedang dalam menyelesaikan soal pemecahan masalah matematika, berikut disajikan lembar jawaban dan wawancara dengan peserta didik KN pada Gambar 2. Sebelumnya, untuk soal nomor 2, yaitu:

"Dalam sistem koordinat lebah bergerak dari titik $(0,0)$ dengan mengikuti pola: 2 satuan ke bawah dan 1 satuan ke kanan, 2 satuan ke atas dan 1 satuan ke kiri, dan begitu seterusnya. Tentukan koordinat lebah setelah bergerak 10 kali!"
Sedangkan, untuk hasil wawancara adalah sebagai berikut (P: Penanya dan KN: Subjek Penelitian).

$\mathrm{P}$ : Mengurangi pola ke bawah sama ke atas kak

$\mathrm{KN}$ : Kenapa begitu?

$\mathrm{P}$ : Karena...

KN: Di sini ada Adek tuliskan absis. Nah, absis itu apa?

$P$ : Nggak tau kak... hehe

$\mathrm{KN}$ : Kalau untuk yang 0 dikali $10=$ $0,-1$ dikali $10=-10$ dan seterusnya, coba Adek jelaskan maksudnya itu bagaimana?

P : Gini kak, kan di dalam soal yang ditanya itu tentukan koordinat lebah setelah bergerak 10 kali, jadi saya kalikan hasil yang di atas dengan $10,0 \times 10=0$, dan $1 \times 10=-10$, ke bawah dapatnya 0 jadi koordinat lebah bergerak 10 kali adalah $(0,-10)$

$\mathrm{KN}$ : Mengurangi pola ke bawah sama ke atas kak

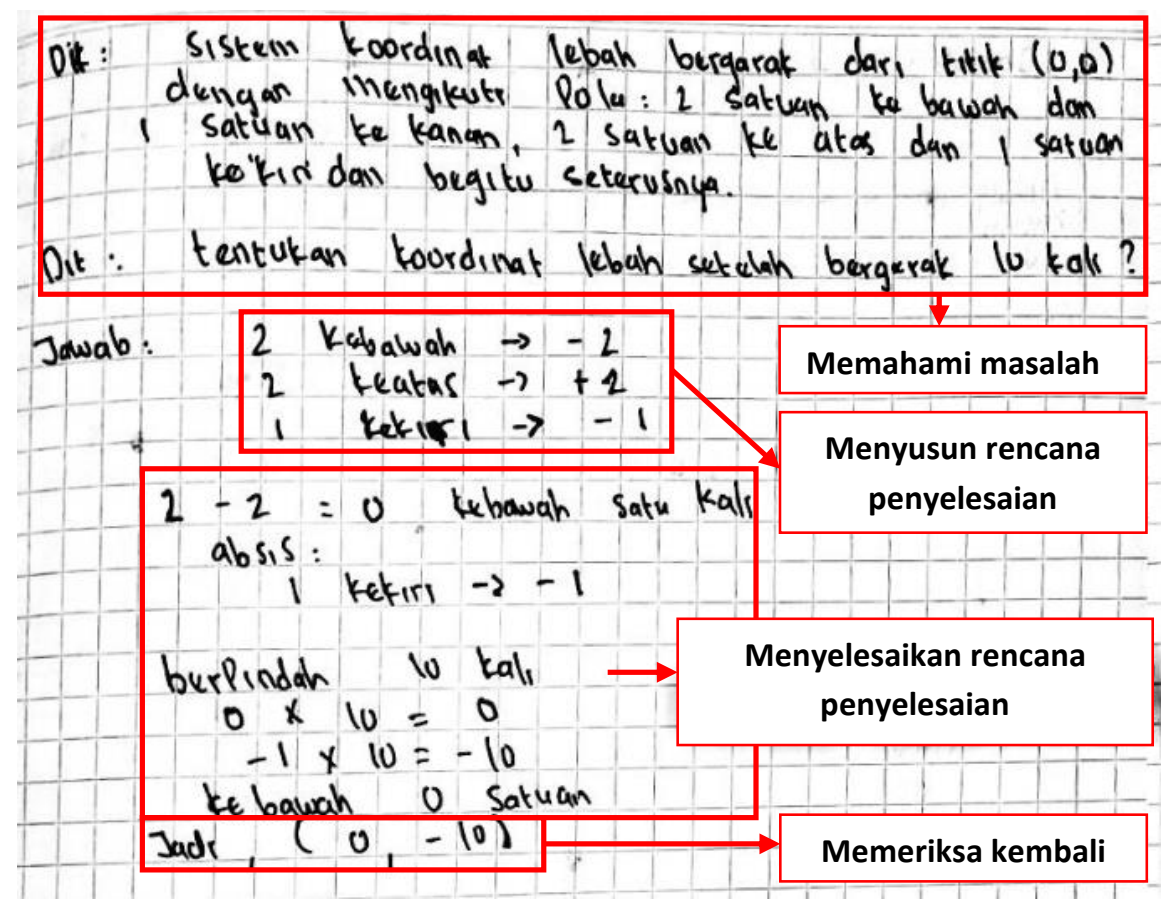

Gambar 2. Lembar jawaban peserta didik dengan minat belajar sedang

Berdasarkan Gambar 2 dan wawancara dengan peserta didik, terlihat bahwa kesulitan peserta didik dalam menyelesaikan rencana 
penyelesaian adalah peserta didik dapat menuliskan penyelesaiannya tetapi masih salah. Peserta didik belum tepat menentukan posisi lebah bergerak berdasarkan pola yang diketahui soal. Peserta didik membuat penyelesaian yang dirinya sendiri tidak paham apa yang ditulisnya. Ketika ditanya, peserta didik tidak dapat memberikan jawaban atas pertanyaan yang diberikan. Berikut disajikan wawancara dengan peserta didik dalam memeriksa kembali.

$P$ : Nah, setelah Adek menyelesaikan soal no.1 ini apakah Adek memeriksa kembali jawaban yang Adek buat?

KN: Tidak kak

$\mathrm{P}$ : Kenapa begitu?

$\mathrm{KN}$ : Lupa kak

$\mathrm{P}$ : Menurut Adek, jawaban Adek ini sudah benar atau bagaimana?

KN: Belum kak

$\mathrm{P}$ : Darimana Adek tau kalau jawaban Adek ini belum benar?

$\mathrm{KN}$ : Karena yang saya buat di nomor 1 itu saya kurang paham kak

Berdasarkan hasil wawancara dengan peserta didik dalam memeriksa kembali, terlihat bahwa kesulitan peserta didik dalam memeriksa kembali adalah peserta didik menuliskan kesimpulan saja dengan kurang tepat dan tidak melakukan pengecekan kembali terhadap proses/ penyelesaian. Letak kesulitan peserta didik tersebut mengalami kesulitan adalah karena peserta didik tidak memahami apa yang ditulisnya dan tidak bisa menjelaskan langkah penyelesaian yang dibuat sehingga hanya mampu menuliskan kesimpulan sesuai hasil yang diperoleh pada saat melakukan penyelesaian.

\section{Minat Belajar Rendah}

Berdasarkan hasil angket minat belajar, peserta didik dengan minat belajar rendah tidak merasa senang tidak tertarik ketika belajar matematika, peserta didik kurang terlibat selama pembelajaran matematika, kurang rajin dan tekun dalam belajar. Untuk mengetahui kesulitan yang dialami peserta didik dalam menyelesaikan soal pemecahan masalah matematika, berikut disajikan lembar jawaban dan wawancara dengan peserta didik HAF dalam menjawab soal nomor 3 pada Gambar 3.

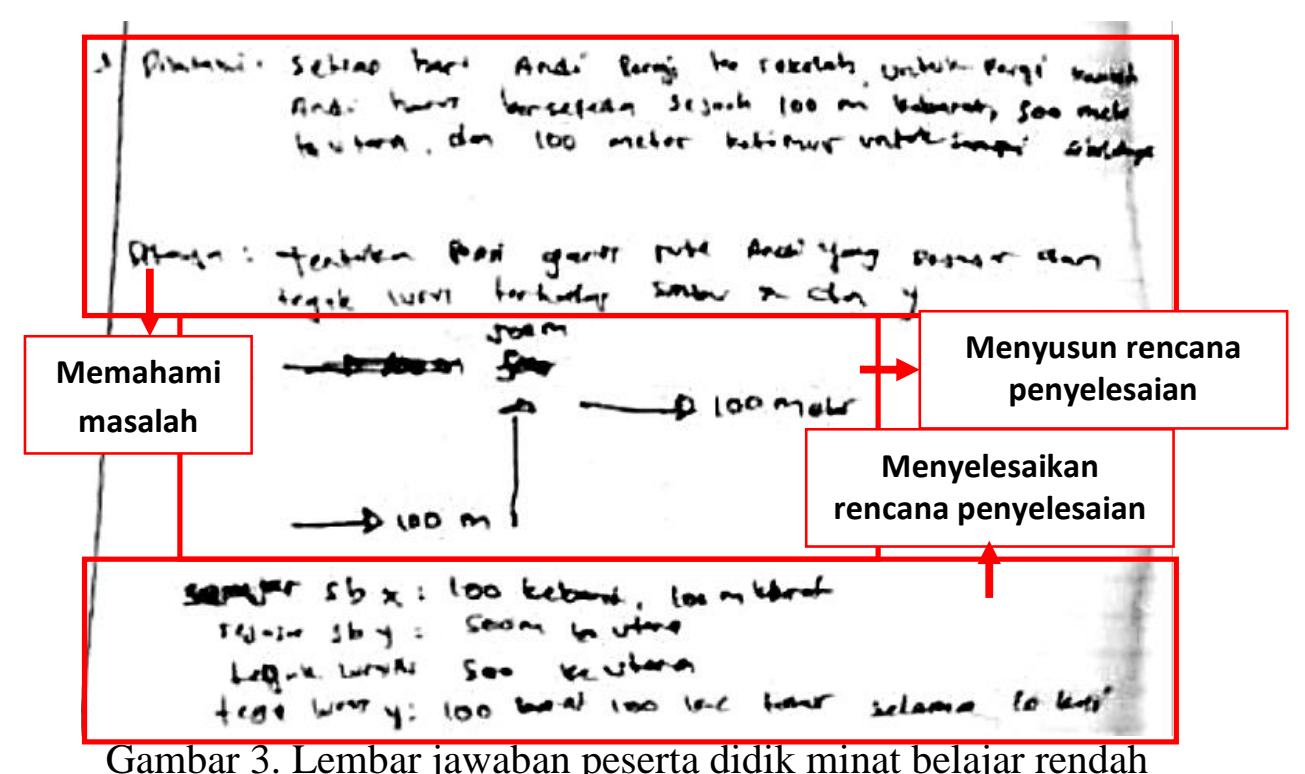

Gambar 3. Lembar jawaban peserta didik minat belajar rendah 
DOI: https://doi.org/10.24127/ajpm.v10i2.3510

Sedangkan, untuk hasil wawancara adalah sebagai berikut! (P: Penanya dan HAF: Subjek Penelitian).

$P$ : Setelah Adek membuat diketahui dan ditanya, apa langkah pertama atau strategi pertama yang Adek lakukan untuk menjawab soal ini?

HAF: Langsung rute Andi $100 \mathrm{~m}$ ke barat, $500 \mathrm{~m}$ ke utara dan 100 $\mathrm{m}$ ke timur kak

$\mathrm{P} \quad$ : Kalau arah barat ke mana dek?

HAF: Ke kanan kak

Berdasarkan Gambar 3 dan hasil wawancara dengan peserta didik, terlihat bahwa kesulitan peserta didik dalam menyusun rencana penyelesaian adalah tidak dapat membuat strategi penyelesaian berupa diagram/ tabel/ model matematika/ data lainnya berdasarkan apa yang diketahui dan ditanyakan soal. ketika ditanya tentang arah mata angin, peserta didik tidak dapat menentukannya dengan tepat. Peserta didik menyebutkan $100 \mathrm{~m}$ ke arah barat adalah $100 \mathrm{~m}$ ke kanan, seharusnya adalah $100 \mathrm{~m}$ ke kiri. Berikut disajikan wawancara dengan peserta didik dalam menyelesaikan rencana penyelesaian.

$P$ : Coba adek perhatikan jawabannya, benar atau salah yang $100 \mathrm{~m}$ ke arah barat tersebut?

HAF: Eh iya salah kak

$\mathrm{P}$ : Untuk mencari posisi garis rute Andi yang sejajar dan tegak lurus sumbu $x$ dan y bagaimana cara Adek mencarinya?

HAF: Yang sejajar sumbu x itu $100 \mathrm{~m}$ ke arah barat, yang sejajar sumbu y itu $500 \mathrm{~m}$ ke utara sebanyak 10 kali

P : Kakak tanya, 10 kali itu dapatnya darimana?
HAF: Oiya nggak ada ya kak

Berdasarkan hasil wawancara tersebut, peserta didik menunjukkan bahwa kesulitan dalam menyelesaikan rencana penyelesaian adalah peserta didik dapat menuliskan penyelesaiannya dengan banyak kesalahan. Peserta didik menentukan garis rute Andi yaitu $100 \mathrm{~m}$ ke barat adalah ke arah kanan, seharusnya ke kiri. Peserta didik juga menjawab garis yang sejajar sumbu $\mathrm{y}$ adalah $500 \mathrm{~m}$ ke utara sebanyak 10 kali, seharusnya $500 \mathrm{~m}$ ke utara saja. Berikut disajikan wawancara dengan peserta didik dalam memeriksa kembali.

$\mathrm{P}$ : Nah, setelah Adek menyelesaikan soal no.3 ini apakah Adek memeriksa kembali jawaban yang Adek buat?

HAF: Tidak kak

$\mathrm{P}$ : Kira-kira menurut Adek, jawaban Adek ini sudah benar atau bagaimana?

HAF: Nggak tau kak...

Berdasarkan hasil wawancara dengan peserta didik tersebut, terlihat bahwa kesulitan peserta didik dalam memeriksa kembali adalah peserta didik tidak menuliskan kesimpulan serta tidak melakukan pengecekan kembali proses dan hasil jawabannya. Peserta didik hanya membuat bidang koordinat dan langkah penyelesaian untuk menentukan garis yang sejajar dan tegak lurus terhadap sumbu $\mathrm{x}$ dan sumbu y tanpa menuliskan kesimpulan. Ketika ditanya apakah jawaban yang ditulis atau tidak, peserta didik menjawab tidak tahu.

Faktor Penyebab Kesulitan Dalam Pemecahan Masalah Matematika

Faktor yang menyebabkan terjadinya kesulitan dalam pemecahan masalah matematika salah satunya ialah 
minat belajar. Hal ini sejalan dengan pendapat (Hidayanti, 2019) yang menyebutkan bahwa tidak adanya minat seseorang dalam belajar akan menimbulkan kesulitan dalam pemecahan masalah.

\section{Minat Belajar Tinggi}

Berdasarkan hasil angket dan wawancara terhadap peserta didik dengan minat belajar tinggi diperoleh informasi bahwa peserta didik mengalami kesulitan dalam pemecahan masalah disebabkan oleh belum terfokus dengan materi yang dijelaskan guru dan peserta didik juga kurang bersemangat untuk menyelesaikan soal matematika tidak rutin.

\section{Minat Belajar Sedang}

Berdasarkan hasil angket dan wawancara terhadap peserta didik dengan minat belajar sedang diperoleh informasi bahwa peserta didik mengalami kesulitan dalam pemecahan masalah disebabkan karena peserta didik kadang tidak mengerti dengan materi yang diberikan, belum terfokus dengan materi yang dijelaskan guru serta peserta didik tidak bersemangat menyelesaikan soal matematika tidak rutin.

Minat Belajar Rendah

Berdasarkan hasil angket dan wawancara terhadap peserta didik dengan minat belajar rendah diperoleh informasi bahwa peserta didik mengalami kesulitan dalam pemecahan masalah disebabkan peserta didik bosan belajar matematika, tidak menyukai pelajaran matematika karena matematika itu banyak menggunakan rumus, belum terfokus dengan materi yang dijelaskan guru, tidak memiliki semangat untuk menyimak materi yang diberikan guru, tidak berani mengemukakan pendapat dan tidak bersemangat menyelesaikan soal matematika tidak rutin.

Dari pembahasan hasil angket, tes pemecahan masalah matematika, dan wawancara maka diperoleh kesulitankesulitan dalam pemecahan masalah dan faktor-faktor yang menyebabkan terjadinya kesulitan dalam pemecahan masalah matematika yang dialami oleh peserta didik di kelas VIII.7 SMP Negeri 31 Padang. Berikut ini kesulitankesulitan yang dialami oleh peserta didik yang disajikan pada Tabel 1 .

Tabel. 1 Kesulitan yang dialami oleh peserta didik

\begin{tabular}{lll}
\multirow{2}{*}{ Kesulitan } & \multicolumn{2}{c}{ Peserta Didik } \\
\cline { 2 - 3 } & Minat tinggi & Minat sedang Minat rendah
\end{tabular}

Memahami masalah
Menyusun rencana penyelesaian
Menyelesaikan rencana penyelesaian
Memeriksa kembali

Dari pembahasan lembar jawaban, wawancara dan tabel di atas dapat diperoleh informasi bahwa peserta didik dengan minat belajar tinggi mengalami lebih sedikit kesulitan dalam memecahkan permasalahan dibandingkan dengan peserta didik minat belajar sedang dan peserta didik

$\begin{array}{lll}- & - & - \\ - & - & \sqrt{ } \\ - & \sqrt{ } & \sqrt{ } \\ \sqrt{ } & \sqrt{ } & \sqrt{ }\end{array}$

dengan minat belajar rendah. Peserta didik dengan minat belajar sedang mengalami lebih sedikit kesulitan dalam memecahkan permasalahan dibandingkan dengan peserta didik minat belajar rendah. Sehingga dapat disimpulkan bahwa peserta didik dengan minat tinggi, sedang dan rendah mengalami 
kesulitan yang berbeda-beda dalam pemecahan masalah matematika. Hal ini sejalan dengan penelitian (Hermaini, 2020) yang menyatakan bahwa kemampuan pemecahan masalah matematis peserta didik ditinjau dari minat belajar peserta didik dengan minat tinggi, sedang, dan rendah memiliki kemampuan penyelesaian soal dari tiap tahapan indikator penyelesaian masalah yang berbeda-beda. Faktorfaktor yang menyebabkan terjadinya kesulitan dalam pemecahan masalah matematika peserta didik di tiap tingkatan minat belajar ada yang sama ada pula yang berbeda.

Implikasi penelitian ini guru hendaknya dapat membangkitkan minat belajar peserta didik agar lebih baik lagi dengan menggunakan model/ pendekatan pembelajaran yang sesuai dan mampu menciptakan lingkungan belajar matematika yang menyenangkan. Tidak hanya itu, dalam proses pembelajaran peserta didik dibiasakan mengerjakan soal-soal pemecahan masalah. Masalah yang diberikan harus sesuai dengan kondisi kognitif peserta didik, artinya masalah yang diberikan dapat dimengerti oleh peserta didik hanya saja solusinya belum segera diketahui (Saputra \& Andriyani, 2018). Masalah yang diberikanpun hendaknya bersifat menantang sehingga membangkitkan minat peserta didik dalam menyelesaikannya. Hal ini dilakukan guna meminimalisir terjadinya kesulitan peserta didik dalam menyelesaikan pemecahan masalah matematika kedepannya.

\section{KESIMPULAN DAN SARAN}

Berdasarkan hasil penelitian dan pembahasan dapat disimpulkan bahwa peserta didik dengan minat belajar tinggi mengalami kesulitan dalam memeriksa kembali, peserta didik dengan minat belajar sedang mengalami kesulitan dalam menyelesaikan rencana penyelesaian dan memeriksa kembali, serta peserta didik dengan minat belajar rendah mengalami kesulitan dalam menyusun rencana penyelesaian, menyelesaikan rencana penyelesaian dan memeriksa kembali. Kesulitan dalam pemecahan masalah matematika disebabkan oleh peserta didik bosan belajar matematika,tidak menyukai pelajaran matematika, belum terfokus dengan materi yang dijelaskan guru, tidak memiliki semangat untuk menyimak materi yang diberikan guru, tidak berani mengemukakan pendapat dan tidak bersemangat menyelesaikan soal matematika tidak rutin.

Penelitian ini berfokus pada kesulitan dalam pemecahan masalah matematika ditinjau dari minat belajar peserta didik akan tetapi masih banyak faktor-faktor yang mempengaruhi kesulitan dalam pemecahan masalah matematika. Oleh sebab itu, sebaiknya perlu dikembangkan ke penelitian berikutnya untuk mengetahui bagaimana kesulitan peserta didik dalam pemecahan masalah matematika yang ditinjau dari aspek lainnya.

\section{DAFTAR PUSTAKA}

Albay, E. M. (2019). Social Sciences \& Humanities Open Analyzing the effects of the problem solving approach to the performance and attitude of fi rst year university students. Social Sciences \& Humanities Open, 1(1), 100006. https://doi.org/10.1016/j.ssaho.201 9.100006

Ariani, S., Hartono, Y., \& Hiltrimartin, C. (2017). Kemampuan Pemecahan Masalah Matematika Siswa pada Pembelajaran Matematika Menggunakan Strategi Abduktif-Deduktif di SMA Negeri 
DOI: https://doi.org/10.24127/ajpm.v10i2.3510

1 Indralaya Utara. Jurnal Elemen, 3(1), 25. https://doi.org/10.29408/ jel.v3i1.304

Hendriana, H., Rohaeti, Sumarno, E. E. \&, \& Utari. (2017). Hard Skills dan Soft Skills Matematik Siswa. PT Refika Aditama.

Herlambang. (2013). Analisis Kemampuan Pemecahan Masalah Matematika Siswa Kelas vii SMP negeri 1 Kepahiang Tentang Bangun datar Ditinjau Dari Teori Van Hiele. Tesis Program Sarjana Pendidikan Matematika FKIP Universitas Bengkulu, h. 14.

Hermaini, J. (2020). Analisis Kemampuan Pemecahan Masalah Matematis Peserta Didik Ditinjau Dari Minat Belajar. Skripsi Program Sarjana Pendidikan Matematika Universitas Islam Negeri Sultan Syarif Kasim Riau.

Hidayanti, R. (2019). Analisis Kesulitan Siswa Dalam Memecahkan Masalah Sistem Persamaan Linear Dua Variabel (SPLDV) Ditinjau Dari Kesadaran Metakognisi. Skripsi Program Sarjana Matematika Universitas Negeri Makassar.

Khasanah, N., Kusmayadi, T. A., \& Nurhasanah, F. (2021). Analisis Kesulitan Dalam Menyelesaikan Masalah Abstraksi Matematis Pada Pokok Bahasan Fungsi. AKSIOMA: Jurnal Program Studi Pendidikan Matematika, 10(1), 359-366.

Komariyah, S., Afifah, D. S. N., \& Resbiantoro, G. (2018). Analisis Pemahaman Konsep Dalam Memecahkan Masalah Matematika Ditinjau Dari Minat Belajar Siswa. SOSIOHUMANIORA: Jurnal Ilmiah Ilmu Sosial Dan Humaniora, 4(1), $1-8$.

https://doi.org/10.30738/sosio.v4i1.1 477

Mahdayani, R. (2016). Analisis Kesulitan Siswa dalam Pemecahan Masalah Matematika pada Materi Aritmetika, Aljabar, Statistika, dan Geometri.
Jurnal Pendas Mahakam, 1(1), 8698.

Milles dan Huberman. (1992). Analisis Data Kualitatif. Universitas Indonesia Press.

Muhammad Daud Siagian. (2016). Kemampuan Koneksi Matematika Dalam Pembelajaran Matematika. MES (Journal of Mathematics Education and Science), 2, 58-67.

National Countil of Teachers of Mathematics. (2000). Principles and Standards for School Mathematics. Journal of Equine Veterinary Science, $\quad 18(11), \quad 719$. https://doi.org/10.1016/s07370806(98)80482-6

Rasiman, F. A. (2016). Analisis Kesulitan Siswa Smp Dalam. Jurnal Ilmiah Pendidikan Matematika, 1(2), 415430.

Ruhyana. (2016). Analisis Kesulitan Siswa Dalam Pemecahan Masalah Matematika. Jurnal Computech \& Bisnis, 10(2), 106-118.

Sapitri, Y., Utami, C., \& Mariyam. (2019). Analisis Kemampuan Pemecahan Masalah Matematis Siswa dalam Menyelesaikan Soal Open-Ended pada Materi Lingkaran Ditinjau dari Minat Belajar. VARIABEL, 2(1), 16-23.

Saputra, N. N., \& Andriyani, R. (2018). Analisis Kemampuan Metakognitif Siswa SMA Dalam Proses Pemecahan Masalah. AKSIOMA: Jurnal Program Studi Pendidikan Matematika, $\quad 7(3), \quad 473$. https://doi.org/10.24127/ajpm.v7i3.1 403

Sulistiyorini, \& Setyaningsih, N. (2016). Analisis Kesulitan Siswa Dalam Pemecahan Masalah Soal Cerita Matematika Pada Siswa SMP. Prosiding Seminar Nasional Pendidikan Matematika, 1-9. 